\title{
Immunohistochemical and serological aspects of Toxoplasma gondii infection in Neotropical primates
}

\author{
Aspectos imuno-histoquímicos e sorológicos da infecção por \\ Toxoplasma gondii em primatas neotropicais
}

\author{
Marta Regina Grumann'; Zigomar da Silva²; José Roberto Silva Filho ${ }^{3}$; \\ Marcio Machado Costa ${ }^{4}$ Maria Isabel Botelho Vieira ${ }^{5}$; Adriana Costa da Motta ${ }^{6 *}$
}

\begin{abstract}
Toxoplasmosis, a disease caused by the intracellular coccidian Toxoplasma gondii that infects most warm-blooded vertebrates, is widely distributed and fatal for primates, which are peculiarly susceptible for unknown reason(s). Owing to the increasing number of Neotropical mammal deaths where in T. gondii were detected in analyzed tissues, the present immunohistochemical study analyzed the distribution patterns of immunostainings related to this parasite on primates necropsied at the Laboratório de Patologia Animal of Universidade de Passo Fundo (UPF), between the years of 2000 and 2014. Furthermore, a serological survey for the disease was conducted for 21 primates from the UPF Zoo, Rio Grande do Sul, Brazil, belonging to genera Sapajus and Alouatta. In a immunohistochemical test performed using streptavidin-biotin-peroxidase, $26.53 \%$ positivity was detected in 98 primates. Immunostainings revealed that infection differed among the lung (76.92\%), liver (58.33\%), heart (50\%), brain $(42.30 \%)$, and kidney $(23.07 \%)$ tissues. Serology performed through indirect hemagglutination showed reactivity in $85.7 \%$ of the animals, all belonging to Sapajus sp., while the three primates that did not show reactivity (14.3\%) belonged to Alouatta sp.
\end{abstract}

Key words: Immunohistochemical. Primates. Toxoplasmosis. Zoonosis. Zoo.

\section{Resumo}

A toxoplasmose é causada por Toxoplasma gondii, um coccídeo intracelular que infecta a maioria dos vertebrados homeotérmicos. Esta doença, de ampla distribuição mundial, é fatal em primatas neotropicais, os quais apresentam uma suscetibilidade peculiar, ainda não elucidada. Dado o crescente número de óbitos em primatas com fortes indícios da presença de $T$. gondii nos tecidos, o presente estudo imuno-histoquímico teve por objetivo verificar o padrão de distribuição de imunomarcações relativas a este parasita nos primatas necropsiados no Laboratório de Patologia Animal da Universidade de Passo Fundo (UPF), entre os anos 2000 e 2014. Realizou-se, ainda, um inquérito sorológico para $T$. gondii em 21 primatas neotropicais dos generous Sapajus e Alouatta pertencentes ao Zoológico da UPF,

\footnotetext{
${ }^{1}$ Discente, Curso de Mestrado do Programa de Pós-Graduação em Bioexperimentação, Faculdade de Agronomia e Medicina Veterinária, FAMV, Universidade de Passo Fundo, UPF, Campus I, Passo Fundo, RS, Brasil. E-mail: martagrumann@hotmail. com

2 Discente, Curso de Graduação em Medicina Veterinária, PIBIC, Laboratório de Patologia Animal, LPA, Hospital Veterinário, HV, FAMV, UPF, Passo Fundo, RS, Brasil. E-mail: zigomar.vet@gmail.com

${ }^{3}$ Médico Veterinário, Zôo, Instituto de Ciências Biológicas, UPF, Passo Fundo, RS, Brasil. E-mail: vetselvagem@outlook.com

${ }^{4}$ Prof. Dr., Curso de Medicina Veterinária, Laboratório de Análises Clínicas, HV, FAMV, UPF, Passo Fundo, RS, Brasil. E-mail: marciocosta@upf.br

${ }^{5}$ Prof $^{\mathrm{a}} \mathrm{Dr}^{\mathrm{a}}$, Curso de Medicina Veterinária, Laboratório de Doenças Parasitárias, HV, FAMV, UPF, Passo Fundo, RS, Brasil. E-mail: marisabel@upf.br

${ }^{6}$ Prof $^{\mathrm{a}} \mathrm{Dr}^{\mathrm{a}}$, Curso de Medicina Veterinária, LPA, HV, FAMV, UPF, Passo Fundo, RS, Brasil. E-mail: acmotta@upf.br

* Author for correspondence
} 
Rio Grande do Sul, Brasil. A imuno-histoquímica realizada através do método da streptavidina-biotinaperoxidase detectou $26,53 \%$ de positividade em 98 primatas. A distribuição das imunomarcações variou entre os tecidos analisados: pulmão $(76,92 \%)$, fígado $(58,33 \%)$, coração $(50 \%)$, cérebro $(42,30 \%)$, e rins $(23,07 \%)$. A sorologia dos 21 primatas, realizada através de hemaglutinação indireta, exibiu reatividade em $85,7 \%$ dos animais, todos pertencentes ao gênero Sapajus, e os três animais negativos $(14,3 \%)$ pertenciam ao gênero Alouatta.

Palavras-chave: Imuno-histoquímica. Primatas. Toxoplasmose. Zoonose. Zoológico.

\section{Introduction}

Toxoplasmosis is a disease caused by Toxoplasma gondii, intracellular parasitic coccidia infecting most homeothermic vertebrates (WOLF, 2003; LINDSAY; DUBEY, 2007). The parasite can be transmitted through the ingestion of sporulated oocysts found in cat feces or cysts infecting raw or undercooked meat, or transplacentally, when primary infection occurs during pregnancy (INNES, 1997; DUBEY; LINDSAY, 2004).

The disease presents acute or chronic forms, depending on the parasite-host interaction (INNES, 1997; DUBEY et al., 1998), and is commonly severe and acute in Neotropical primates, which show a peculiar, not yet elucidated, susceptibility (ANDERSON; McCLURE, 1993; INNES, 1997). Such susceptibility might be related to the arboreal habits of primates, which lead to their non-exposure to feline feces (INNES, 1997). Clinically, the disease progresses rapidly and the animals die suddenly (EPIPHANIO et al., 2003; GYIMESI et al., 2006; SALANT et al., 2009). Although the relationships between host susceptibility, parasite genotype, and parasite virulence are not entirely known (PELÁEZ et al., 2011), the severity of the clinical condition in Neotropical species seems to be independent of the strain involved (SALANT et al., 2009).

In acute cases, the organs affected include the lungs, liver, spleen, lymph nodes, intestine, and brain, resulting in the replication and rupture of host cells by tachyzoites leading to tissue necrosis (EPIPHANIO et al., 2003). In cases where there is a good immune response of the host to the parasite, the infection becomes chronic, and it is thus possible to observe the presence of cysts formed by bradyzoites in the brain, skeletal muscles, and heart (DUBEY et al., 2004).

Owing to lack of information on $T$. gondii infections in Neotropical primates inhabiting the north of Rio Grande do Sul (RS) state, the present work aimed to investigate the distribution of the parasite in the tissues of primates necropsied at the Animal Pathology Laboratory (APL) by performing an immunohistochemical study. A serological survey was also performed in captive populations of Alouatta sp. and Sapajus sp. kept at the University of Passo Fundo (UPF) Zoo.

\section{Material and Methods}

Samples

This research was authorized by the Ethics Committee on Animal Use of the UPF, RS, under proposal no. 006/2013 and registration no. 015/2012.

Tissues of all the primates sent to the Animal Pathology Laboratory of the University of Passo Fundo (APL-UPF) for necropsy between 2000 and 2014, and preserved in paraffin blocks, were selected for the present study based on the availability of paraffin blocks and degree of tissue autolysis. Overall, tissues from 98 male and female primates, mostly adults, and belonging to several genera were studied. Genus Alouatta was the most frequent, with 45 individuals (45.91\%), followed by Sapajus sp., with 21 individuals (21.42\%), Callithrix sp. with 14 individuals (14.28\%), and Papio sp. and Aotus sp., with two individuals each (2.04\%); eight individuals were unidentified $(8.16 \%)$.

Because part of the samples collected during the study period came from captive primates at 
the UPF Zoo, a serological study was performed to complement the information obtained via immunohistochemistry (IHC) assays. Blood samples were collected from 21 primates, including 17 Sapajus nigritus, 1 Sapajus apella, and 2 Alouatta guariba kept at the UPF Zoo, by performing the standard procedure of physical containment and using a dip net and leather gloves. Venipuncture was performed on the femoral vein to obtain $3 \mathrm{ml}$ of blood from each animal. These samples were centrifuged and their sera separated into aliquots.

\section{Immunohistochemical assays}

To perform IHC assays, the liver, kidney, lung, heart, and brain tissues preserved in paraffin blocks were selected (CUNNINGHAM et al., 1992; EPIPHANIO et al., 2003; ANDRADE et al., 2007). After sectioning paraffin blocks, the streptavidinbiotin-peroxidase method was performed in immunolabeling, using diaminobenzene (DAB) as the chromogen and polyclonal anti-T. gondii antibodies (1:100 dilution; code Z2197, Zeta Corporation; Sierra Madre, CA, USA). The sections were counterstained with hematoxylin and analyzed under an optical microscope. Positive controls from previously tested positive cases (OLIVEIRA et al., 2009) were also used.

\section{Serology}

The indirect hemagglutination (IHA) test was performed for the qualitative determination of anti-T. gondii antibodies using the Immuno-HAI ${ }^{\circledR}$ Toxoplasmosis Kit (Laboratório Wama Diagnóstica; São Carlos, SP, BR). The IHA technique was performed according to the manufacturer's recommendations, using the serum of the animals to be tested diluted to $1 / 32$ in a ready-to-use diluent solution. Tests had a positive and negative control for a correct interpretation of the results.

\section{Statistical analysis}

The data obtained in the IHC assays (immunostaining of the different tissues) were analyzed using descriptive statistics and the results were expressed in absolute (total) and relative (percentage) frequencies. The data obtained in the serological analysis (positive and negative results) were analyzed through a contingency table, followed by Fisher's exact test, instead of Pearson's chi-square test, because the expected frequencies were lower than $5 \%$. Results were considered statistically different when $p<0.05$. The SPSS statistical package, version 20.0, was used for data analysis.

\section{Results}

\section{Immunohistochemistry}

Immunostaining was observed in 26 of the 98 primates examined, thus producing $26.53 \%$ of positive results. The genus Alouatta had the highest frequency, with 15 of the 45 individuals showing positive results $(33.33 \%)$, followed by Callithrix (5 of 19; 26.31\%), and Sapajus (4 of 22; 18.18\%). Among the genera with the lowest number of individuals showing positive immunostaining were Papio, Aotus, and other unidentified genera (2 of $12 ; 16.66 \%)$.

Twenty cases showed immunostaining in the lung $(76.92 \%), 14$ in the liver $(58.33 \%), 13$ in the heart (50\%), 11 in the brain $(42.30 \%)$, and 6 in the kidneys $(23.07 \%)$. In seven cases, immunostaining was only observed in one of these organs $(26.92 \%)$, whereas in 19 cases, staining was observed in two or more organs $(73.07 \%)$.

Regarding localization, immunostaining patterns differed among the studied organs and, in most cases, there was simultaneous immunostaining at more than one site within the same tissue (Table 1). 
Table 1. Toxoplasma gondii infectious stages distribution and their immunostaining frequency in each studied organ of the 26 primates necropsied in at the Animal Pathology Laboratory of the University of Passo Fundo, according to the immunohistochemistry assays performed using streptavidin-biotin-peroxidase.

\begin{tabular}{|c|c|c|c|c|}
\hline Organ & Infectious stage & Distribution & $\begin{array}{c}\text { Absolute } \\
\text { frequency }\end{array}$ & $\begin{array}{c}\text { Relative } \\
\text { frequency }\end{array}$ \\
\hline \multirow[t]{5}{*}{ Lung } & Tachyzoites & Interstitial & $19 / 20$ & $95 \%$ \\
\hline & & Alveolar macrophages & $7 / 20$ & $35 \%$ \\
\hline & Cysts & Interstitial & $15 / 20$ & $75 \%$ \\
\hline & & Alveolar macrophages (Figure 1A) & $6 / 20$ & $30 \%$ \\
\hline & & Close to the alveolar sacs (Figure 1B) & $1 / 20$ & $5 \%$ \\
\hline \multirow[t]{8}{*}{ Liver } & Tachyzoites & Hepatocytes & $8 / 14$ & $57.14 \%$ \\
\hline & & Kupffer cells (Figure 1C) & $9 / 14$ & $64.28 \%$ \\
\hline & & Portal tract & $1 / 14$ & $7.14 \%$ \\
\hline & & Central lobe region & $1 / 14$ & $7.14 \%$ \\
\hline & Cysts & Hepatocytes & $14 / 14$ & $100 \%$ \\
\hline & & Kupffer cells & $6 / 14$ & $42.85 \%$ \\
\hline & & Inflammation areas & $1 / 14$ & $7.14 \%$ \\
\hline & & Central lobe region & $1 / 14$ & $7.14 \%$ \\
\hline \multirow[t]{2}{*}{ Heart } & Tachyzoites & Muscle fibers & $8 / 13$ & $61.53 \%$ \\
\hline & Cysts & Muscle fibers & $11 / 13$ & $84.61 \%$ \\
\hline \multirow[t]{4}{*}{ Brain } & Tachyzoites & Neuropil (Figure 1C) & $7 / 11$ & $63.63 \%$ \\
\hline & & Necrotizing encephalitis (Figure 1D) & $1 / 11$ & $9.09 \%$ \\
\hline & Cysts & Neuropil & $10 / 11$ & $90.90 \%$ \\
\hline & & Necrotizing encephalitis & $1 / 11$ & $9.09 \%$ \\
\hline \multirow[t]{4}{*}{ Kidneys } & Tachyzoites & Tubular cells & $3 / 6$ & $50 \%$ \\
\hline & & Macrophages & $2 / 6$ & $33.33 \%$ \\
\hline & & Location could not be determined due to autolysis & $1 / 6$ & $16.66 \%$ \\
\hline & Cysts & Tubular cells & $5 / 6$ & $83.33 \%$ \\
\hline
\end{tabular}


Figure 1. Immunohistochemistry assays performed for detecting Toxoplasma gondii. A) Lung. Immunostaining in interstitial cells. Cyst and tachyzoites (curved arrow), and cyst in macrophage (arrow). B) Lung. Immunostaining in cysts, close to alveolar sacs (arrow). C) Liver. Immunostaining in hepatocytes (curved arrow), and Kupffer cells (arrow) and in areas of degeneration and hepatocellular necrosis. Cysts and tachyzoites. D) Brain. Immunostaining close to necrotizing encephalitis. Cysts (arrow) and tachyzoites (curved arrow). Magnification $=400 \mathrm{X}$ in all photomicrographs.

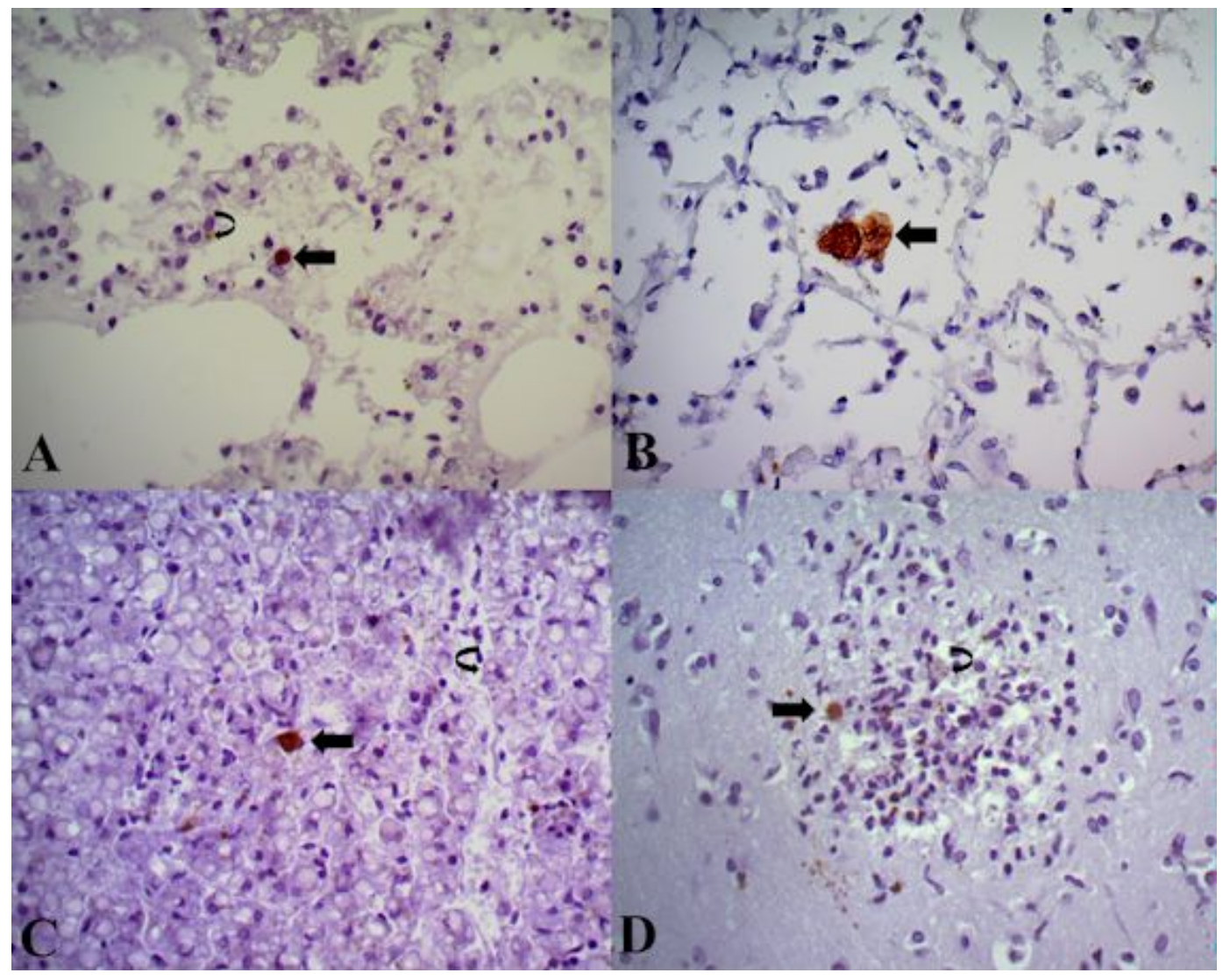

\section{Serology}

Serological tests were positive in 18 primates $(85.7 \%)$ and negative in $3(14.3 \%)$. The studied genera differed, as all positive animals were Sapajus spp. while the negative ones were $A$. guariba (Table 2).

Table 2. Prevalence of anti-Toxoplasma gondii antibodies in primates of the genera Sapajus and Alouatta, kept at the Zoo of the University of Passo Fundo, Rio Grande do Sul, Brazil, obtained using the indirect hemagglutination qualitative technique.

\begin{tabular}{cccc}
\hline & Sapajus sp. & Alouatta sp. & Total \\
\hline Positive & $18(85.7 \%)$ & $0(0.0 \%)$ & $18(85.7 \%)$ \\
Negative & $0(0.0 \%)$ & $3(14.3 \%)$ & $3(14.3 \%)$ \\
Total & $18(85.7 \%)$ & $3(14.3 \%)$ & $21(100 \%)$ \\
\hline & & $\mathbf{D F}$ & $\boldsymbol{P}$ \\
Fisher's exact test & & 1 & $<0,001^{*}$ \\
\hline
\end{tabular}

$\mathrm{DF}=$ degrees of freedom; *values lower than 0.05 indicate a significant difference. 


\section{Discussion}

The IHC assay performed in the present study was an important tool for the identification of T. gondii in tissues and, consequently, in the confirmation of the disease. The advantage of using IHC was also reported by Motta et al. (2008) and Silva et al. (2013a), who obtained similar results in sheep tissues. Although toxoplasmosis can be presumptively diagnosed through histopathology, as structures compatible with this protozoan can be visualized (ROSA et al., 2001; SILVA; LANGONI, 2001), a definitive diagnosis can be obtained using IHC (ANDRADE et al., 2007; CASAGRANDE et al., 2013), which emphasizes the relevance of this test for diagnostic certification.

In our study, both cysts and tachyzoites were found throughout the brain and myocardial tissues of Alouatta, Callithrix, and Sapajus specimens. Cysts and tachyzoites are commonly distributed in several organs, although cysts are more prevalent in neurologic or muscular tissues (DUBEY et al., 2004).

Mononuclear inflammatory infiltration and necrosis have occasionally been observed in association with immunostaining. Neurological lesions such as necrotizing encephalitis, first detected in hematoxylin e eosin staining (HE), showed structures that suggested the presence of the protozoan and have also been reported in humans with HIV (KUMAR et al., 2010). According to Navia et al. (1986), in cerebral toxoplasmosis, the lesions show a necrotizing organized or abscessive pattern and tissue damage caused by the infection, and require host's immune response. Similar to the findings of Casagrande et al. (2013), the structures observed in the present study were pyriformor oval, found free or inside macrophages, and intralesional. In addition, immunohistochemical staining was observed in the cytoplasm of macrophages or free, mainly in the lung and liver. Through the immunohistochemical assays for T.gondii performed on captive primates, the parasite also detected in the liver, kidney, lung, heart, and brain tissues, with reactions having different intensities (CUNNINGHAM et al., 1992; EPIPHANIO et al., 2003; ANDRADE et al., 2007). In addition, staining has also been described in mesenteric lymph nodes (ANDRADE et al., 2007), lymph nodes, spleen, adrenal gland, arteries, large and small intestines, pancreas, adipose tissue, bone marrow, uterus, ovaries, testis, thyroid, neurohypophysis, mesentery, tongue, tonsils, and skeletal muscle (EPIPHANIO et al., 2003).

Toxoplasma gondii is responsible for the increased mortality of Neotropical primates, both free-living and captive, as they frequently develop acute and fatal infections. Acute episodes of toxoplasmosis in monkey squirrels (Saimiri sciureus) have been reported in several zoos around the world (SALANT et al., 2009) and 100\% morbidity and $30 \%$ mortality were reported in a colony of 17 primates (CUNNINGHAM et al., 1992). Although the cause of such high mortality rates has not been clarified, the sensitivity reported for New World primates was similar to that of immunocompromised humans (CUNNINGHAM et al., 1992). The results of the immunohistochemical assays performed in the present study indicated that the disseminated form of the disease affected many animals. This fact, together with the high frequency of seropositive animals revealed by the serological test, corroborates the afore mentioned theory.

In Brazil, serological investigations on Neotropical primates showed variable results and in most cases, as in the present study, the percentage of seropositive animals was high. At the Wild Animal Triage Center/IBAMA, Seropédica, Rio de Janeiro, Brazil, 16 of the 21 Sapajus sp. individuals (76.2\%) showed a serological reaction (PIRES et al., 2012). High percentages were also found in Paraná (13 of 43; 30.2\%) (GARCIA et al., 2005), São Paulo (3 of 5; $60 \%$ ) (SANCHIS et al., 1972), and Mato Grosso do Sul (4 of 13; 30.8\%) (LEITE et al., 2008). However, in an ecological station in São Paulo, only 3 of 36 (8.33\%) capuchin monkeys (Sapajus apella) were 
seroreactive (SILVA et al., 2013b); however, unlike the UPF's Zoo primates, these were free-living.

In conclusion, IHC was useful to identify $T$. gondii in tissue fragments in paraffin blocks, for a short or long period, and in observing the distribution patterns of the protozoan in primate tissues. Although the necropsied animals were not serologically evaluated, the serological survey carried out on UPF's Zoo primate populations demonstrated that $T$. gondii infection was highly prevalent, corroborating the results of the immunohistochemical study.

\section{Acknowledgments}

We thank the Research Support Foundation of the State of Rio Grande do Sul (FAPERGS) and University of Passo Fundo (UPF) for financial support.

\section{References}

ANDERSON, D. C.; McCLURE, H. M. Toxoplasmosis. In: JONES T. C.; MOHR U.; HUNT R. D. (Ed.). Nonhuman primates I. New York: Springer-Verlag, 1993. p. 63-69.

ANDRADE, M. C. R.; COELHO, J. M. C. O.; AMENDOEIRA, M. R. R.; VICENTE, R. T.; CARDOSO, C. V. P. C.; FERREIRA, C. B.; MARCHEVSKY, R. S. Toxoplasmosis in squirrel monkeys: histological and immunohistochemical analysis. Ciência Rural, Santa Maria, v. 37, n. 6, p. 1724-1727, 2007.

CASAGRANDE, R. A.; TIFFANY, C. E. S.; PESCADOR, C. A.; BORELLI, V.; SOUZA JUNIOR, J. C.; SOUZA, E. R.; TRAVERSO, S. D. Toxoplasmose em primatas neotropicais: estudo retrospectivo de sete casos. Pesquisa Veterinária Brasileira, Seropédica, v. 33, n. 1, p. 94-98, 2013.

CUNNINGHAM, A. A.; BUXTON, D.; THOMSON, K. M. Epidemic of toxoplasmosis in a captive colony of squirrel monkeys (Saimiri sciureus). Journal of Comparative Pathology, Amsterdam, v. 107, n. 2, p. $207-$ 219, 1992.
DUBEY, J. P.; GRAHAM, D. H.; DE YOUNG, R. W.; DAHL, E.; EBERHARD, M. L.; NACE, E. K.; WON, K.; BISHOP, H.; PUNKOSDY, G.; SREEKUMAR, C.; VIANNA, M. C. B.; SHEN, S. K.; KWOK, O. C. H.; SUMNERS, J. A.; DEMARAIS, S.; HUMPHREYS, J. G.; LEHMANN, T. Molecular and biologic characteristics of Toxoplasma gondii isolates from wildlife in the United States. Journal of Parasitology, Lawrence, v. 90, n. 1, p. 67-71, 2004.

DUBEY, J. P.; LINDSAY, D. S. Biology of Toxoplasma gondii in Cats and Other Animals. In: LINDSAY, D. S.; WEISS, L. M. (Ed.). Opportunistic infections: toxoplasma, sarcocystis and microsporidia. New York: Kluwer Academic Publishers, 2004. p. 1-19.

DUBEY, J. P.; LINDSAY, D. S.; SPEER, C. A. Structures of Toxoplasma gondii tachyzoites, bradyzoites, and sporozoites and biology and development of tissue cystes. Journal of Clinical Microbiology, Washington, v. 11, n. 2, p. 267-299, 1998.

EPIPHANIO, S.; SINHORINI, I. L.; CATÃO-DIAS, J. L. Pathology of toxoplasmosis in captive new world primates. Journal of Comparative Pathology, Amsterdam, v. 129, n. 2, p. 196-204, 2003.

GARCIA, J. L.; SVOBODA, W. K.; CHRYSSAFIDIS, A. L.; MALANSKI, L. S.; SHIOZAWA, M. M.; AGUIAR, L. M.; TEIXEIRA, G. M.; LUDWIG, G.; SILVA, L. R.; HILST, C.; NAVARRO, I. T. Sero-epidemiological survey for toxoplasmosis in wild New World monkeys (Cebus sp., Alouatta caraya) at Paraná river basin, Paraná State, Brazil. Veterinay Parasitology, Amsterdam, v. 133, n. 4, p. 307-311, 2005.

GYIMESI, Z. S.; LAPPIN, M. R.; DUBEY, J. P. Application of assays for the diagnosis of toxoplasmosis in a colony of woolly monkeys (Lagothrix lagotricha). Journal of Zoo and Wildlife Medicine, Yulee, v. 37, n. 3, p. 276-280, 2006.

INNES, E. A. Toxoplasmosis: comparative species susceptibility and host immune response. Comparative Immunology, Microbiology \& Infectious Diseases, Amsterdam v. 20, n. 2, p. 131-138, 1997.

KUMAR, G. G. S.; MAHADEVAN, A.; GURUPRASAD, A. S.; KOVOOR, J. M. E.; SATISHCHANDRA, P.; NATH, A.; KUMAR, R. U.; SHANKAR, S. K. Eccentric target sign in cerebral toxoplasmosis - neuropathological correlate to the imaging feature. Journal of Magnetic Resonance Imaging, Malden, v. 31, n. 6, p. 1469-1472, 2010. 
LEITE, T. N. B.; MAJA, T. A.; OVANDO, T. M.; CANTADORI, D. T.; SCHIMIDT, I. R.; GUÉRCIO, A. C.; CAVALCANTI, A.; LOPES, F. M. R.; CUNHA, I. A. I.; NAVARRO, I. T. Ocorrência de infeccção por Leishmania spp. e Toxoplasma gondii em macacos-prego (Cebus apella) de Campo Grande, MS. Revista Brasileira de Parasitologia Veterinária, Jaboticabal, v. 17, n. 1, p. 307-310, 2008.

LINDSAY, D. S.; DUBEY, J. P. Toxoplasmosis in wild and domestic animals. In: WEISS, L.; KAMI, K. A. (Ed.). Toxoplasma gondii: the model apicomplexan perspectives and methods. London: Academic Press, 2007. p. 133-152.

MOTTA, A. C. da; VIEIRA, M. I. B.; BONDAN, C.; EDELWEISS, M. I. A.; DAMETTO, M. A.; GOMES, A. Aborto em ovinos associado à toxoplasmose: caracterização sorológica, anatomopatológica e imunoistoquímica. Revista Brasileira de Parasitologia Veterinária, Jaboticabal, v. 17, p. 204-208, 2008. Suplemento 1.

NAVIA, B. A.; PETITO, C. K.; GOLD, J. W. M.; CHO, E.; JORDAN, B. D.; PRICE, R. W. Cerebral toxoplasmosis complicating the acquired immune deficiency syndrome: clinical and neuropathological findings in 27 patients. Annals of Neurology, Malden, v. 16, n. 3, p. 224-238, 1986.

OLIVEIRA, E. C.; PESCADOR, A. P.; SONNE, L.; PAVARINI, S. P.; CORBELLINI, L. G.; DRIEMEIER, D. Análise imuno-histoquímica de cães naturalmente infectados pelo parvovirus canino. Pesquisa Veterinária Brasileira, Seropédica, v. 29, n. 2, p. 131-136, 2009.

PELÁEZ, C. C.; TORRES, C. P. R.; GARRIDO, C. G. S.; CORREA, D. Acute toxoplasmosis in squirrel monkeys (Saimiri scirieus) in Mexico. Veterinary Parasitology, Amsterdam, v. 180, n. 3-4, p. 368-371, 2011.

PIRES, J. S.; RIBEIRO, C. T.; CARVALHO-FILHO, P. R.; PISSINATTI, A.; FLAUSINO, W.; LOPES, C. W. G. Infection by Toxoplasma gondii in Neotropical non-human primates. Pesquisa Veterinária Brasileira, Seropédica, v. 32, n. 10, p. 1041-1044, 2012.
ROSA, C.; KASAI, N.; SOUZA, S. L. P.; GUERRA, J. L.; REGO, A. A.; GENNARI, S. M. Comparação das técnicas de imuno-histoquímica e bioensaio em camundongos para pesquisa de Toxoplasma gondii em tecidos de caprinos, experimental mente inoculados. Arquivos do Instituto Biológico, São Paulo, v. 68, n. 1, p. 13-17, 2001.

SALANT, H.; WEINGRAM, T.; SPIRA, D. T.; EIZENBERG, T. An outbreak of Toxoplasmosis amongst squirrel monkeys in a Israel monkey colony. Veterinary Parasitology, Amsterdam, v. 159, n. 1, p. 24-29, 2009.

SANCHIS, F. S.; JAMRA, L. F.; GUIMARÃES, E. C.; DEANE, M. P. Toxoplasmose espontânea em animais domésticos e silvestres, em São Paulo. Revista do Instituto de Medicina Tropical de São Paulo, São Paulo, v. 14, n. 5, p. 314-320, 1972.

SILVA, A. F.; OLIVEIRA, F. C. R.; LEITE, J. S.; MELLO, M. F. V.; BRANDÃO, F. Z.; LEITE, R. I. J. C. K.; FRAZÃO-TEIXEIRA, E.; LILENBAUMA, W.; FONSECA, A. B. M.; FERREIRA, A. M. R. Immunohistochemical identification of Toxoplasma gondii in tissues from Modified Agglutination Test positive sheep. Veterinary Parasitology, Amsterdam, v. 191, n. 3-4, p. 347-352, $2013 \mathrm{a}$.

SILVA, A. V.; LANGONI, H. The detection of Toxoplasma gondii by comparing cytology, histopatology, bioassay in mice and the polymerase chain reaction (PCR). Veterinary Parasitology, Amsterdam, v. 97, n. 3, p. 191 $198,2001$.

SILVA, R. C.; MACHADO, G. P.; CRUVINEL, T. M. A.; CRUVINEL, C. A.; LANGONI H. Frequency of Toxoplasma gondii antibodies in tufted capuchin monkeys (Cebus paella nigritus) from an ecological station in the State of São Paulo, Brazil. Pesquisa Veterinária Brasileira, Seropédica, v. 33, n. 2, p. 251 253, $2013 \mathrm{~b}$.

WOLF, B. A. Toxoplasmosis. In: FOWLER, M. E.; MILLER, R. E. (Ed.). Zoo and wild animal medicine. Philadelphia: Saunders, 2003. p. 745-749. 